\title{
Evolution of Nutritional Management of Acute Malnutrition
}

\author{
Michael H Golden \\ Emeritus Professor, University of Aberdeen, Scotland. \\ Correspondence to: Pollgorm, Ardbane,Downings, County Donegal, Ireland.mike@pollgorm.net,mikegolden@wanadoo.fr
}

\begin{abstract}
Wasting, kwashiorkor and stunting are not usually due to either protein or energy deficiency. Treatment based upon this concept results in high mortality rates, and failure of treated children to return physiologically to normal. They become relatively obese with insufficient lean tissue. Preventive strategies have also failed. Wasting and stunting are primarily due to deficiency of type II nutrients and kwashiorkor probably due to deficiency of several type I nutrients that confer resistance to oxidative stress. Modern dietary treatments are based upon the F75 formula whilst the child is sick without an appetite, followed by F100 for rapid gain of weight. Derivative, ready-to-use therapeutic foods (RUTF) allow treatment of large numbers of children at home, are preferred by mothers and dramatically improve coverage. Children are indentified by screening in the community and treated before complications arise, using simple protocols.
\end{abstract}

Successful treatment of the sick children with severe malnutrition not only depends upon these products, but appropriate management of complications. The physiology of the malnourished child is completely different from the normal child and many drugs and treatments that are safe in children with normal physiology are fatal for the malnourished child. In particular, the diagnosis and management of diarrhea and dehydration is different in the malnourished child. Giving standard treatment frequently leads to circulatory overload and death from heart failure.

The challenge now is to find successful local ways to prevent malnutrition and achieve nutritional security. Until prevention works, we have to rely on fortified foods for treatment and convalescence from illness.

Key words: F100, Malnutrition, RUTF, Therapy, Treatment.

$\mathrm{T}$ he treatment of severe malnutrition has been dominated by concepts of its etiology. Recently these concepts have changed dramatically. Instead of administering abundant protein and energy and treating the complications as one would do in a normal child, the pathophysiological changes and detailed studies of the metabolism of individual nutrients have been used to formulate diets and guidelines for the management of severe malnutrition and its complications. This has resulted in a dramatic fall in case fatality rates. It should be emphasized that nearly all physiological, biochemical and immunological systems in the body are changed in the malnourished individual. This is brought about by a mixture of reductive adaptation to the inadequate intake, nutritional imbalance and deficiency of specific nutrients and to the resulting effects of infection and other environmental stresses that cannot be adequately resisted because of the physiological and immunological changes.

\section{Historical Perspective}

Malnutrition has been recognized for millennia as being due to a shortage of food. Ancel Keys lists many of the famines recorded in history(1) which disappeared when the normal diet of the population returned. Kwashiorkor as a separate entity was recognized early in Latin America and called "multideficiency syndrome"(2) and in Europe as "flour dystrophy"(3). Later it was described from Africa by Cecile Williams in the English literature(4-6), given the name kwashiorkor, and recorded as responding to milk. After a brief argument whether this was a form of pellagra(7) most experts accepted that the cause was protein deficiency(8-11), a view that has persisted(12) particularly among those who invested their life's work investigating protein metabolism 
and deficiency on the basis that it would illuminate kwashiorkor.

Marasmus was thought to be due to energy deficiency as failure to give sufficient energy always leads to weight loss and dietary surveys showed a low energy intake in marasmic children. Starvation was studied extensively during and after the Second World War(1) and the etiology assumed to apply to marasmic children. This led to the treatment of all types of malnutrition with high-protein, high-energy diets and the naming of these forms of malnutrition as first protein-calorie malnutrition and then proteinenergy malnutrition (which is still the Index Medicus and International Classification of Diseases nomenclature).

\section{Protein and Energy Deficiency}

The first real attack on the protein deficiency theory of kwashiorkor came from Gopalan(13) where he found that the antecedent diets of children with kwashiorkor and marasmus were not different in terms of protein, a finding that has since been confirmed $(14,15)$. Shrikantia then ascribed the edema of kwashiorkor to the antidiuretic effects of ferritin, which he found elevated in edematous malnutrition(16,17). This seminal work was discounted internationally because the paper was not in a peer reviewed journal and the electrolyte pattern did not usually accord with an antidiuretic effect. Importantly, there was no alternative paradigm at that time so that the protein hypothesis was not abandoned.

The next advance was to show that children could lose all their edema without a change in plasma albumin level(18) and that protein intake was not associated with rates of recovery(19). Furthermore, the high ferritin values found by Srikantia were also confirmed(20). These children have liver dysfunction with reduced levels of amino acid metabolizing enzymes and abnormal urinary metabolites(21-27). One would not give high levels of protein to a child with an inborn error of aminoacid metabolism. It is unfortunate that the studies of the livers of malnourished children, showing similar defects, albeit acquired, should not have been translated into clinical practice and led to the restriction of protein in the diet of malnourished children. In Somalia mortality fell when protein was restricted in the diets of severely malnourished adult patients(28) (mortality on high and moderate protein diets - edematous $51 \%$ vs $25 \%, P<0.05$, marasmic $22 \%$ vs $13 \%, P=0.08)$. There then developed the concept of kwashiorkor being due to a lack of antioxidant nutrients(29,30), a hypothesis which has not been confirmed by intervention trials(31) despite evidence of oxidative damage in the same population(32).

It is incontrovertible that if sufficient food is not taken, for whatever reason, the child will lose weight and become marasmic. This was interpreted as energy deficiency and the treatment response was to give additional energy in the diet. Furthermore, metabolic studies showed that wasted children's rates of weight gain were closely related to their energy intake. For this reason, the energy density of the diets was increased by the addition of lipid (3335) to limits where water deficiency and hypernatraemic dehydration were real possibilities. The reason for the decreased energy intake could of course be starvation, and it is notable that those that get marasmus are almost always dependent upon others for food: infants and children, prisoners, the elderly, infirm, mentally ill and indigent.

\section{Appetite}

One of the clinical features of nearly all malnourished children is a loss of appetite and a flattening of affect. It does not take much of a reduction in appetite to cause a loss of weight. Thus, if body tissue requires $5 \mathrm{kcal}$ to synthesize one gram of tissue(36), and a similar shortfall in intake will cause a loss of one gram of tissue, then a child whose energy requirement for maintenance is $100 \mathrm{kcal} / \mathrm{kg} /$ d, but takes only $90 \mathrm{kcal} / \mathrm{kg} / \mathrm{d}$, to give a shortfall of $10 \mathrm{kcal} / \mathrm{kg} / \mathrm{d}$, will lose $2 \mathrm{~g} / \mathrm{kg} / \mathrm{d}$. In 10 days the child will lose $2 \%$ of body weight and in 3 months $20 \%$ of body weight to be classified as malnourished (assuming no metabolic adaptation).

Appetite is a measure of metabolic wellbeing. It is particularly disturbed with liver dysfunction, during the metabolic response to infection(37) and with deficiency of certain essential nutrients. During 
these conditions, loss of appetite is the main reason for weight loss(37,38); with infection, during convalescence with a good diet there is an increased appetite and regain of lost weight(39). The studies that show a relationship between infection and malnutrition are cross-sectional statistical analyses this effect is not seen with longitudinal studies where under normal circumstances acute infection does not result in wasting $(40,41)$ after convalescence. Provision of improved sanitation, although it prevents diarrhea has no effect on malnutrition prevalence(42); some reviews that suggest the opposite are highly critical of any study that does not show a positive effect and exclude negative studies on methodological grounds whereas positive studies are viewed less stringently(41,43). Even policies such as hand washing, for which there is no evidence that it will prevent malnutrition, are vigorously promoted over nearly all other interventions to provide the at-risk child with wholesome food or promote nutritional security with higher quality diets (44). Biased and inappropriate analysis is common when considering the causes of malnutrition.

One of the most potent causes of loss of appetite in all experimental animals is a dietary imbalance of certain nutrients, and malnourished children given traditional weaning foods normally have a reduced appetite $(37,45)$. If diminution of appetite is due to deficiency of a specific nutrient in the habitual diet of the children, then dietary surveys will indeed show that they have a reduced energy intake, but this will not be due to energy deficiency and not be corrected by giving additional energy in the form of carbohydrate or lipid. It will only be cured by giving the specific nutrients that are missing in the habitual diet that cause the loss of appetite. A good example comes from the relatively affluent USA, the appetites of children given zinc supplements improved and they started to catch up in height(46). From these realizations, the theory of type I (functional nutrients) and type II nutrients was generated(47-50). The implication is that if protein deficiency is involved in malnutrition the clinical expression will be marasmus and not kwashiorkor, however other type II nutrients, such as zinc, phosphorus or magnesium are likely to become limiting in the diet before protein(51). If the diet is poor then when weight is lost from an infection, there will be insufficient type II nutrient density to allow for catch-up growth during convalescence. Zinc is frequently the limiting type II nutrient, although not always(52); the effect of zinc on convalescence from diarrhea, now a world-wide WHO promoted intervention, is simply a specific example of a general phenomenon. There has to be sufficient and the right balance of type II nutrients in the diet to promote convalescence. If the diets were adequate there would be no requirement for zinc supplements for the recovering child. Perhaps the supplement should contain all the type II nutrients in balance and be given to all children after an acute weight loss.

If kwashiorkor is not due to protein deficiency and marasmus is not usually due to energy deficiency, then the name "protein-energy malnutrition" gives quite the wrong message and leads to inappropriate treatment of the malnourished individual. This nomenclature has not only led to quite inappropriate policy decisions but also probably led to deaths.

Based upon the protein-energy deficiency theories, diets were devised and tested in large scale trials. They either failed to prevent malnutrition of all sorts, or had a marginal effect. An influential review of these programs(53) led to disillusionment with "food" shortage as a cause of malnutrition, and the focus switched to infection as the primary cause, a view which persists to this day(44) particularly among medical doctors who study infectious disease in detail during training, but have little understanding of nutrition. This led to massive investment in water and sanitation programs. Although improved sanitation prevents mortality and morbidity from water-borne infection, it does not prevent stunting, wasting or edematous malnutrition any more than the trials of improving diets in protein and energy.

The other concept, to which many non-medical personnel subscribe, is that poor mothers are ignorant and that education is the main intervention required. This is reminiscent of the apocryphal remark ascribed to Mari-Antoinette before the French revolution when the poor could not find 
bread: "Let them eat cake". The poor are experts at surviving on very meager resources; very few privileged people, who make decisions on behalf of the poor, would survive if they found themselves impoverished to the degree where the poor survive with few prospects and incredible monotony. Undoubtedly, poverty is closely associated with malnutrition and the interventions that consistently impact upon malnutrition are those that increase disposable income; even the successful water programs can be interpreted as increasing harvests and thus income. It is wrong to blame the mothers for being poor. With increased income the diet is diversified so that with a variety of foods the risk of deficiency of an essential nutrient is minimized.

\section{Potassium and Magnesium}

Potassium and magnesium have been found to be essential for treatment of the malnourished for at least 50 years. The tissues are grossly depleted in these elements and there is a strongly positive balance during recovery [see references in Golden 2009(36)]. Diets of dried skimmed milk, sugar, oil, potassium and magnesium (so called "high energy milk”) have been the mainstay of the diets used to treat severe malnutrition from the 1960s until recently.

Despite criticism(54) more than 20 years ago, most relief foods, such as CSB, UNIMIX and indigenous complementary and low-cost foods for infants and young children, including Indiamix, still do not contain any added potassium or magnesium. It would appear that it can take 50 years for scientific work to leave the shelf of the library and affect programs, particularly when the current concepts and teaching of the etiology and pathogenesis of malnutrition are at variance with the proposed intervention.

\section{QUALITY OF RECOVERY ON OLDER DIETS}

Numerous studies were done on children recovering on high-energy milk diets in the units researching malnutrition. Clinically the children recovered well with rates of weight gain of $1 \%$ to $2 \%$ of body weight per day; they reached the median of the growth standards weight-for-height. There remained about $10 \%$ mortality in the best centers of the world and a much higher mortality in typical clinical settings(55).

For physiological studies, it was common practice to compare the results of the child when malnourished with the same child after recovery, to avoid problems of inter-individual variability in response. Even though the abnormalities improved during treatment(56) they usually did not return to those seen in normal children. For example, renal concentrating ability remained severely compromised $(57,58)$ and glucose intolerance and insulin secretion remained abnormal(59). Their body composition was also abnormal with much greater accumulation of adipose tissue than lean tissue $(60,61)$; this was confirmed in Peru where nitrogen balance studies showed almost no nitrogen retention on such a diet(62). These are all profound abnormalities that had not recovered on the diets that were given at the time. The persistent abnormalities were ascribed to damage caused by severe malnutrition and not amenable to treatment. Clinicians were satisfied because the children gained weight to reach normal values and physiological assessment is rarely conducted and such abnormalities are not clinically apparent.

As zinc was thought to be the limiting nutrient in the diet at that time, we gave zinc to previously malnourished children who had recovered to the median weight-for-height. We observed a significant increase in the size of their thymus glands(63), increased skin delayed hypersensitivity response(64), stimulation of the sodium pump and correction of their intracellular electrolyte concentrations(65) and increased muscle instead of adipose tissue synthesis $(66,67)$. The results obtained with additional zinc showed that the persistent pathology was not due to irreversible changes of malnutrition, but due to inadequacies of the treatment at that time: at least zinc was required in the diets. However, once zinc was provided, the next limiting type II nutrient could restrict full recovery.

\section{The F100 Diet And Derivative Foods}

With the development of the type I, type II classification of the essential nutrients(47), we examined balance studies and tissue concentrations 
of all the type II nutrients and used a factorial approach to design a diet that would provide all the building blocks for resynthesis of normal body tissues. This diet was tested and found to return body composition and metabolites to normal(68).

The diet (F100) was then used by the agency Action Contra le Faim in emergency settings in Africa and found to promote rapid recovery of the children(69). It was incorporated into a protocol for the management of severe malnutrition(50). This protocol was offered to the World Health Organization for their consideration in 1992. WHO organized its review and verification which found that it lowered mortality rates substantially(70), and it was adapted and published independently by the reviewers of the manuscript used by WHO(71). It was adopted formally by WHO in 1999(72) and has given rise to several derivative works.

Because F100 is a liquid milk-based diet, it had to be used in health facilities to prevent misuse. In many settings it is not possible for mothers to leave their families for extended periods or to travel long distances. Home treatment is by far the best option and has been tried successfully for children after the first phase of management $(73,74)$ in stable countries. However, in most situations we did not have a suitable safe recovery diet to use at home. A lipid-based, anhydrous version of F100 was developed as a paste(75). Termed, ready-to-use therapeutic food (RUTF), it has since undergone extensive trials and protocols have been adapted to incorporate both in and outpatient management of the severely malnourished(76,77). This has been a major advance. Before a limited number of children were kept in hospitals and treated mainly by doctors who did not properly understand malnutrition using relatively complicated protocols that were difficult to apply; there remained a high mortality(78). Now hundreds of thousands of children are treated, between $80 \%$ and $90 \%$ at home using simple protocols $(79,80)$.

The type I, type II concept has since spread to the treatment of moderately malnourished children and to the prevention of wasting and stunting. The use of relatively small amounts of fortified foods that contain all the essential nutrients in a balance that promotes growth and development(36) to populations at very high risk of famine has led to prevention of severe and moderate malnutrition and prevention of stunting $(81,82)$ and a very high acceptability among the beneficiary population. Of critical importance, during these studies there was no education campaign and no change in public health services, sanitation or water supply. The provision of the supplementary food was the only intervention. Provision of such spreads do not undermine breastfeeding practices(83).

However, this approach is relatively expensive and not sustainable and should only be used in situations with an alarming prevalence of malnutrition or impending famine. These studies do not give a practical solution to the massive problem of malnutrition in stable situations, where up to half the children of the world are chronically malnourished and half of all deaths have malnutrition as the underlying cause. The importance of the findings is the vindication of the concept that wasting and stunting are not primarily due to either lack of care or responsibility by the mothers on the one hand or poor sanitation and hygiene on the other hand. Neither is malnutrition usually due to energy deficiency, even, perhaps surprisingly, in situations of acute food shortage. These results also confirm the importance of the type I, type II classification of the essential nutrients and re-establish the lack of adequate wholesome food which contains appropriate amounts of all the essential nutrients at the center of the etiology of malnutrition. We can now understand why concentration on protein and energy and equating adequate "food" supply (which usually means a cereal and pulse) with adequate provision of all essential nutrients failed(53) and why the massive investment in water, sanitation, public health and education programs have addressed many problems, but have failed to address the problem of malnutrition. When families have more disposable income they increase the quality of their diets, as exemplified by diversifying their diets and taking more animal foods, which are associated with a low prevalence of malnutrition(84-88).

\section{The First Phase of Treatment}

When severely wasted or edematous children are 
first admitted, they have changes in all their physiological processes, compromised liver, renal and intestinal function and frequently have infections, small bowel bacterial overgrowth and very poor appetites. The F100 diet is not appropriate.

A second diet was devised based upon the known physiological changes that occur in the most severe cases. It was designed not to allow growth, to have very low levels of sodium, protein and iron, abundant potassium, magnesium, zinc, the type I nutrients and be more easily absorbed by patients with compromised intestinal function. Phosphorus is the limiting nutrient in F75. It was initially called FTS standing for formula for toxic shock; this was later changed to F75. It should be emphasized that this formula is quite distinct in its composition from F100; it is not simply a dilute form of F100. On this diet the children lose their edema, resynthesise their enzymatic machinery and their physiology starts to return to normal. The children signal the start of their recovery by regaining their appetites.

The WHO (1999) protocol and it's antecedents introduced a lower sodium, higher potassium solution for the management of dehydration. This was based upon the changes in body electrolytes with a reduction of the sodium pump, an increase in intra-cellular sodium and reduction in intracellular potassium(89-91). During treatment the sodium pump is stimulated, large amounts of intracellular sodium comes out of the cells, potassium enters the cells, the circulating blood volume increases and the hemoglobin drops from dilutional anemia. The children are at risk of acute heart failure(92-96) and sudden death(97).

During a major evaluation of the application of the drafts of the WHO protocol(98) in 23 centers in Africa, it was found that most children who died had gained weight shortly before they died; this was interpreted as being due to positive fluid balance(98). Death with positive fluid balance is most likely due to fluid overload and circulatory failure. It became clear that the WHO protocol laid insufficient emphasis on the diagnosis and treatment of dehydration and the dangers of its misdiagnosis and mistreatment. New algorithms were introduced and restrictions placed upon the use of oral rehydration fluids of all kinds. These changes are incorporated into more modern protocols(76,77). On the other hand, there is undue emphasis in the WHO protocol on some aspects of treatment, which consume staff time, make the implementation difficult and divert attention from those provisions which are important to prevent mortality. The new protocol for malnutrition has resulted in a further fall in mortality for in-patients to less than $5 \%$.

\section{Moderate Malnutrition}

The changing definitions of severe and moderate malnutrition means that many of the older studies classified what we now consider being moderate malnutrition as severe. These children share many of the changes seen in severe malnutrition, albeit often in a milder form (36). The success of treatment of the severely malnourished led us to attempt to improve the food given in supplementary feeding programs as well, largely because there have been such poor results with fortified corn-soy-blends (CSB). We developed a new diet formulation $\left(\mathrm{GBG}^{1}\right)$ and first tested it in Rwanda just after the genocide. The results of a wet feeding program are shown in Table I. On the new diet very few mothers abandoned the program, whereas with the old diet defaulting was a major problem; the beneficiaries voted with their feet and stayed away because they could not see the benefit for the child and attendance have opportunity costs for the family. The rate of weight gain on the CSB was $1.2 \mathrm{~g} / \mathrm{kg} / \mathrm{d}$ and on the GBG $5.1 \mathrm{~g} / \mathrm{kg} / \mathrm{d}$. This is higher than that achieved with many of the current programs using much more expensive lipid based spreads.

We were encouraged by the results and established a factory in Nairobi, Kenya to manufacture food to the GBG formulation. The factory used the same mineral-vitamin mix but used whole soya beans and maize whereas the first study had used dehulled soya and oat flour; the ingredients for the first diet was roasted and in the second were extrusion cooked. The Kenyan product was tested in a refugee camp in Northern Uganda in 1995 and failed to show any difference compared with

\footnotetext{
Golden-Briend-Grellety or GBG mix was manufactured by
} Nutriset whose trade name for the product is SP450. 
TABLE I Effect of Changing From Corn-soy-Blend Supplementary FeEding to Golden-Briend-Grellety (GBG) Formula Porridge (100) On The Outcome Of Moderately Malnourished Children In Cyanika, Rwanda (Nov-Dec 1994)

\begin{tabular}{llllllllll}
\hline Diet & All & \multicolumn{2}{c}{ Cured } & \multicolumn{2}{c}{ Abandoned } & \multicolumn{2}{c}{ Transferred } & \multicolumn{2}{c}{ Death } \\
\cline { 2 - 11 } & $n$ & $n$ & $\%$ & $n$ & $\%$ & $n$ & $\%$ & $n$ & $\%$ \\
\hline Corn-soy-blend & 825 & 423 & 51 & 321 & 39 & 71 & 9 & 10 & 1.2 \\
Corn-soy-blend then GBG mix & 143 & 131 & 92 & 9 & 6 & 2 & 1 & 1 & 0.7 \\
GBG mix & 126 & 102 & 81 & 12 & 9 & 11 & 9 & 1 & 0.8 \\
\hline All & 1094 & 656 & 60 & 342 & 31 & 84 & 8 & 12 & 1.1 \\
\hline
\end{tabular}

UNIMIX, a corn-soy blend. We also found that the new diet did not achieve the expected results in Somalia. Therefore we returned the samples to France and tested them in volunteers and found that the volunteers excreted excessive hydrogen after ingesting the product made in Kenya. Even adult volunteers were malabsorbing the food. We then collected samples of supplementary feeding rations, complementary and weaning foods from round the world and analyzed them for anti-nutrients. All the diets fed to young, moderately malnourished and normal children had easily measureable levels of phytic acid, anti-trypsin, anti-chymotrypsin, antiamalyase, phytohaemagluttinin, saponin and lectins(99). Unfortunately, there are no standards set by the Codex Alimenarious for anti-nutrients in foods, including those for infants or the malnourished. Clearly, the matrix, fiber and antinutrients have the potential to affect the bioavailability of essential nutrients and the integrity of the intestine, particularly when it is already damaged from malnutrition.

\section{ConClusions}

The results of introduction of new products to treat severe malnutrition based upon formulations that return the child to physiological, immunological and biochemical normality has resulted in a dramatic fall in mortality and the ability to treat children rapidly. With the introduction for safe derivative products that can be used at home, there has been a massive expansion of services for the severely malnourished so that they can now be treated in large numbers close to their homes, with minimal family disruption.

INDIAN PEDIATRICS
The expansion of the programs for severe malnutrition to moderate malnutrition with the reversal of wasting and, more interestingly, stunting has confirmed that wasting and stunting are not primarily due to energy deficiency, the quantity of food available, poor care practices or acute infection, although each of these can contribute to malnutrition in a proportion of children. The primary cause is type II nutrient deficiency from very poor quality diets with resulting loss of appetite, growth cessation and failure of convalescence from infection with reductive adaptations that change the ability of the child to respond to environmental stress or resist infections. Most of the children also have type I nutrient deficiency; these nutrients affect specific functions and biochemical pathways in the body so as to compromise health and immunity without necessarily giving rise to wasting, stunting or other anthropometric abnormalities. Normal or obese people can be deficient in type I nutrients as well as the underweight; indeed, taking empty calories will lead to obesity as occurred with the recovered malnourished child on the old inadequate diets. The obese can be severely undernourished. ${ }^{2}$ During treatment the diets have to correct the probable type I deficiencies as well as the type II deficiencies.

The challenge now is to devise sustainable mechanisms to provide the appropriate balance and amounts of all the necessary nutrients, type $\mathrm{II}^{3}$ as well as the type I nutrients, in a bio-available form to

\footnotetext{
${ }^{2}$ It is wrong to think of obesity as over-nutrition. The obese have clearly been in positive energy balance, but may be deficient in many essential nutrients and so be undernourished.
} 
allow the children to grow and develop optimally. Of course, this is best achieved by growing the appropriate mixtures of foods, selecting cultivars with few anti-nutrients, applying traditional and home technologies to increase the bioavailability of nutrients from foods and probably central fortification of milled cereals, sugar or other common commodities with certain nutrients. Nevertheless, it is clear that preventive measures used in the past have all failed; that is the only reason we need therapeutic feeding. With our new understanding of the nature of malnutrition there is a massive research agenda to allow all children and their parents to become nutrient secure as well as food secure with local produce alone. Until the research has been conducted and meaningful and successful ways of ensuring nutrient security for families is achieved, we will need to rely on fortified foods that have been such a success in the recent past for all forms of malnutrition.

Funding: None.

Competing interests: None stated.

\section{REFERENCES}

1. Keys A, Brozeck J, Henschell A, Mickelsen O, Taylor HL. The Biology of Human Starvation. London: Oxford University Press; 1945.

2. Autret M, Behar M. Sindrome policarencial infantil (kwashiorkor) and its prevention in Central America. 13 ed. Rome, Italy: Food and Agriculture Organisation; 1954.

3. Reitschel. Ueber mehle und mehlfutterungen bei sauglingen und ihre beziehungen zum stoffwechsel. Deutsch Med W 1908; 34: 826.

4. Williams CD. A nutritional disease of childhood associated with a maize diet. Arch Dis Child 1933; 8: 423-433.

5. Williams CD. Kwashiorkor: a nutritional disease of children associated with a maize diet. Lancet 1935; 2: $1151-1152$.

6. Williams CD. Kwashiorkor. JAMA 1953; 153: 1280-1285.

\footnotetext{
${ }^{3}$ We should perhaps think of these as the "forgotten nutrients”. Even Western agencies have not set recommended allowances for nutrients like potassium, and phosphorus is set simply in relation to calcium requirements.
}

7. Gillman J, Gillman T. Perspectives in human nutrition. New York: Grune and Stratton; 1951.

8. Dean RFA, Schwartz R. The effects of protein deficiency on young children. Courrier 1954; 4: 293-316.

9. Behar M, Viteri FE, Scrimshaw NS. Treatment of severe protein deficiency in children (kwashiorkor). Am J Clin Nutr 1957; 5: 506-515.

10. Waterlow JC. Protein deficiency in tropical countries. Biol Human Affair 1959; 24: 1-6.

11. Hansen JDL. Nutrition - with special reference to kwashiorkor and protein deficiency. Public Health 1963; 63: 31.

12. Waterlow JC. Kwashiorkor revisited: the pathogenesis of oedema in kwashiorkor and its significance. Trans R Soc Trop Med Hyg 1984; 78: 436-441.

13. Gopalan C. Kwashiorkor and marasmus: evolution and distinguishing features. In: McCance RA, Widdowson EM, editors. Calorie Deficiencies and Protein Deficiencies. London: Churchill; 1968. p. 48-58.

14. Lin CA, Boslaugh S, Ciliberto HM, Maleta K, Ashorn $\mathrm{P}$, Briend $\mathrm{A}$, et al. A prospective assessment of food and nutrient intake in a population of Malawian children at risk for kwashiorkor. J Pediatr Gastroenterol Nutr 2007; 44: 487-493.

15. Sullivan J, Ndekha M, Maker D, Hotz C, Manary MJ. The quality of the diet in Malawian children with kwashiorkor and marasmus. Matern Child Nutr 2006; 2: 114-122.

16. Srikantia SG. Ferritin in nutritional oedema. Lancet 1958; 1: 667-668.

17. Srikantia SG, Gopalan C. Role of ferritin in nutritional oedema. J Appl Physiol 1959; 14: 829833.

18. Golden MH, Golden BE, Jackson AA. Albumin and nutritional oedema. Lancet 1980; 1: 114-116.

19. Golden MH. Protein deficiency, energy deficiency, and the oedema of malnutrition. Lancet 1982; 1 : 1261-1265.

20. Ramdath DD, Golden MH. Non-haematological aspects of iron nutrition. Nutr Res Rev 1989; 2: 2949.

21. Stephen JML, Waterlow JC. Effect of malnutrition 
on activity of two enzymes concerned with aminoacid metabolism in human liver. Lancet 1968; 1: 118-119.

22. Antener I, Verwilghen AM, Van Geert C, Mauron J. Biochemical study of malnutrition. Part VI: Histidine and its metabolites. Int J Vitam Nutr Res 1983; 53: 199-209.

23. Whitehead RG. An unidentified compound in the serum of children with kwashiorkor (proteincalorie malnutrition). Nature 1964; 204: 389.

24. Dean RF, Whitehead RG. The metabolism of aromatic aminoacids in kwashiorkor. Lancet 1963; 1: 188-191.

25. Whitehead RG. Histidine metabolism in kwashiorkor. Lancet 1962; ii: 203-204.

26. Whitehead RG, Milburn TR. Metabolites of phenylalanine in the urine of children with kwashiorkor. Nature 1962; 196: 580-581.

27. Whitehead RG, Arnstein HR. Imidazole acrylic acid excretion in kwashiorkor. Nature 1961; 190: 1105-1106.

28. Collins S, Myatt M, Golden B. Dietary treatment of severe malnutrition in adults. Am J Clin Nutr 1998; 68: 193-199.

29. Golden $\mathrm{MH}$, Ramdath DD, Golden BE. Free radicals and malnutrition. In: Dreosti IE, editor. Trace Elements, Micronutrients and Free Radicals. Totowa, New Jersey: Humana Press; 1991. p. 199222.

30. Golden MH, Ramdath D. Free radicals in the pathogenesis of kwashiorkor. Proc Nutr Soc 1987; 46: 53-68.

31. Ciliberto H, Ciliberto M, Briend A, Ashorn P, Bier D, Manary M. Antioxidant supplementation for the prevention of kwashiorkor in Malawian children: randomised, double blind, placebo controlled trial. Br Med J 2005; 330: 1109-1114.

32. Manary MJ, Leeuwenburgh C, Heinecke JW. Increased oxidative stress in kwashiorkor. J Pediatr 2000; 137: 421-424.

33. Ashworth A. Ad lib feeding during recovery from malnutrition. Br J Nutr 1974; 31: 109-112.

34. Ashworth A, Bell R, James WPT, Waterlow JC. Calorie requirements of children recovering from protein-calorie malnutrition. Lancet 1968; 2: 600603.

INDIAN PEDIATRICS
35. Kerr DS, Ashworth A, Picou DIM, Poulter N, Seakins A, Spady D, et al. Accelerated recovery from infant malnutrition with high calorie feeding. In: Gardner L, Amacher P, editors. Endocrine Aspects of Malnutrition. Santa Ynez, California: Kroc Foundation; 1973. p. 467-86.

36. Golden MH. Proposed recommended nutrient densities for moderately malnourished children. Food Nutr Bull 2009; 30: S267-S342.

37. Brown KH, Stallings RY, de Kanashiro HC, Lopez de RG, Black RE. Effects of common illnesses on infants' energy intakes from breast milk and other foods during longitudinal community-based studies in Huascar (Lima), Peru. Am J Clin Nutr 1990; 52: 1005-1013.

38. Becker S, Black RE, Brown KH. Relative effects of diarrhea, fever, and dietary energy intake on weight gain in rural Bangladeshi children. Am J Clin Nutr 1991; 53: 1499-1503.

39. Miall WE, Desai P, Standard KL. Malnutrition, infection and child growth in Jamaica. J Biosocial Sci 1970; 2: 31-44.

40. Briend A, Hasan KZ, Aziz KM, Hoque BA. Diarrhoea and catch-up growth. Lancet 1990; 335: 1157-1158.

41. Lutter CK, Mora JO, Habicht JP, Rasmussen KM, Robson DS, Sellers SG, et al. Nutritional supplementation: effects on child stunting because of diarrhea. Am J Clin Nutr 1989; 50: 1-8.

42. Hasan KZ, Briend A, Aziz KM, Hoque BA, Patwary MY, Huttly SR. Lack of impact of a water and sanitation intervention on the nutritional status of children in rural Bangladesh. Eur J Clin Nutr 1989; 43: 837-843.

43. Esrey SA, Habicht JP. Epidemiologic evidence for health benefits from improved water and sanitation in developing countries. Epidemiol Rev 1986; 8: 117-128.

44. Black RE, Allen LH, Bhutta ZA, Caulfield LE, de OM, Ezzati M, et al. Maternal and child undernutrition: global and regional exposures and health consequences. Lancet 2008; 371: 243-260.

45. Brown KH, Peerson JM, Lopez de RG, de Kanashiro HC, Black RE. Validity and epidemiology of reported poor appetite among Peruvian infants from a low-income, periurban community. Am J Clin Nutr 1995; 61: 26-32.

46. Krebs NF, Hambidge KM, Walravens PA. 
Increased food intake of young children receiving a zinc supplement. Am J Dis Child 1984; 138: 270273.

47. Golden MH. The role of individual nutrient deficiencies in growth retardation of children as exemplified by zinc and protein. In: Waterlow JC, editor. Linear Growth Retardation in Less Developed Countries. New York: Raven Press; 1988. p. 143-163.

48. Golden MH. The nature of nutritional deficiency in relation to growth failure and poverty. Acta Paediatr Scand Suppl 1991; 374: 95-110.

49. Golden MH. Specific deficiencies versus growth failure: type I and type II nutrients. SCN News 1995; 10-14.

50. Golden MH. Severe malnutrition. In: Weatherall DJ, Ledington JGG, Warrell DA, editors. Oxford Textbook of Medicine. 3 ed. Oxford: Oxford University Press; 1996. p. 1278-1296.

51. Golden MH, Golden BE. Trace elements. Potential importance in human nutrition with particular reference to zinc and vanadium. Br Med Bull 1981; 37: 31-36.

52. Mazariegos M, Hambidge KM, Westcott JE, Solomons NW, Raboy V, Das A, et al. Neither a zinc supplement nor phytate-reduced maize nor their combination enhance growth of 6 - to 12month-old Guatemalan infants. J Nutr 2010; 140: 1041-1048.

53. Beaton GH, Ghassemi H. Supplementary feeding programs for young children in developing countries. Am J Clin Nutr 1982; 35: 864-916.

54. Michaelsen KF, Clausen T. Inadequate supplies of potassium and magnesium in relief food: implications and countermeasures. Lancet 1987; 1: 1421-1423.

55. Schofield C, Ashworth A. Why have mortality rates for severe malnutrition remained so high? Bull World Health Organ 1996; 74: 223-229.

56. Golden $\mathrm{MH}$. The effects of malnutrition in the metabolism of children. Trans R Soc Trop Med Hyg 1988; 82: 3-6.

57. Alleyne GAO. The excretion of water and solute by malnourished children. West Indian Med J 1966; 15: $150-154$.

58. Alleyne GAO. The effect of severe protein calorie malnutrition on the renal function of Jamaican children. Pediatrics 1967; 39: 400-411.
59. James WPT, Coore HG. Persistent impairment of insulin secretion and glucose tolerance after malnutrition. Am J Clin Nutr 1970; 23: 386-389.

60. Brooke OG, Wheeler EF. High energy feeding in protein-energy malnutrition. Arch Dis Child 1976; 51: 968-971.

61. Wheeler EF. Changes in anthropometric measurements of children recovering from proteinenergy malnutrition. Proc Nutr Soc 1975; 34: 35A36A.

62. MacLean WC, Jr., Graham GG. The effect of energy intake on nitrogen content of weight gained by recovering malnourished infants. Am J Clin Nutr 1980; 33: 903-909.

63. Golden MH, Jackson AA, Golden BE. Effect of zinc on thymus of recently malnourished children. Lancet 1977; 2: 1057-1059.

64. Golden MH, Harland PS, Golden BE, Jackson AA. Zinc and immunocompetence in protein-energy malnutrition. Lancet 1978; 1: 1226-1228.

65. Patrick J, Golden BE, Golden MH. Leucocyte sodium transport and dietary zinc in protein energy malnutrition. Am J Clin Nutr 1980; 33: 617-620.

66. Golden $\mathrm{MH}$, Golden BE. Effect of zinc supplementation on the dietary intake, rate of weight gain, and energy cost of tissue deposition in children recovering from severe malnutrition. Am J Clin Nutr 1981; 34: 900-908.

67. Golden BE, Golden MH. Effect of zinc on lean tissue synthesis during recovery from malnutrition. Eur J Clin Nutr 1992; 46: 697-706.

68. Morris A, Golden MH, Ramdath DD. A new recovery diet for use in the treatment of malnutrition. West Indian Med J 1989; 38 (Suppl 1): 64.

69. Golden MH, Briend A. Treatment of malnutrition in refugee camps. Lancet 1993; 342: 360.

70. Ahmed T, Ali M, Ullah MM, Choudhury IA, Haque ME, Salam MA, et al. Mortality in severely malnourished children with diarrhoea and use of a standardised management protocol. Lancet 1999; 353: 1919-1922.

71. Ashworth A, Jackson A, Khanum S, Schofield C. Ten steps to recovery. Child Health Dialogue 1996; 3-4: 10-12.

72. Golden MH. Management of Severe Malnutrition. A Manual for Physicians and Other Senior Health Workers. Geneva: WHO; 1999. 
73. Cooper ES, Headden G, Lawrance C. Caribbean children, thriving and failing, in and out of hospital. J Trop Pediatr 1980; 26: 232-238.

74. Khanum S, Ashworth A, Huttly SR. Controlled trial of three approaches to the treatment of severe malnutrition. Lancet 1994; 344: 1728-1732.

75. Briend A, Lacsala R, Prudhon C, Mounier B, Grellety Y, Golden MH. Ready-to-use therapeutic food for treatment of marasmus. Lancet 1999; 353: 1767-1768.

76. Protocol for the management of severe malnutrition. Addis Ababa: Ethiopian Federal Ministry of Health; 2007.

77. Guidelines for the management of the severely malnourished in Yemen. 1 ed. Sa' ana: Republic of Yemen, Ministry of Public Health and Polulation; 2008.

78. Ashworth A, Chopra M, McCoy D, Sanders D, Jackson D, Karaolis N, et al. WHO guidelines for management of severe malnutrition in rural South African hospitals: effect on case fatality and the influence of operational factors. Lancet 2004; 363: 1110-1115.

79. Linneman Z, Matilsky D, Ndekha M, Maleta K, Manary MJ. A large-scale operational study of home-based therapy with ready-to-use therapeutic food in childhood malnutrition in Malawi. Matern Child Nutr 2007; 3: 206-215.

80. Manary MJ, Ndkeha MJ, Ashorn P, Maleta K, Briend A. Home based therapy for severe malnutrition with ready-to-use food. Arch Dis Child 2004; 89: 557-561.

81. Defourny I, Minetti A, Harczi G, Doyon S, Shepherd S, Tectonidis M, et al. A large-scale distribution of milk-based fortified spreads: evidence for a new approach in regions with high burden of acute malnutrition. PLoS ONE 2009; 4: e5455.

82. Isanaka S, Nombela N, Djibo A, Poupard M, Van $\mathrm{BD}$, Gaboulaud $\mathrm{V}$, et al. Effect of preventive supplementation with ready-to-use therapeutic food on the nutritional status, mortality, and morbidity of children aged 6 to 60 months in Niger: a cluster randomized trial. JAMA 2009; 301: 277-285.

83. Galpin L, Thakwalakwa C, Phuka J, Ashorn P, Maleta K, Wong WW, et al. Breast milk intake is not reduced more by the introduction of energy dense complementary food than by typical infant porridge. J Nutr 2007; 137: 1828-1833.

84. Graham GG, Creed HM, MacLean WC, Jr, Kallman CH, Rabold J, Mellits ED. Determinants of growth among poor children: nutrient intakeachieved growth relationships. Am J Clin Nutr 1981; 34: 539-554.

85. Graham GG, Creed HM, MacLean WC Jr, Rabold J, Kallman CH, Mellits ED. Determinants of growth among poor children: relation of nutrient intakes to expenditure for food. Am J Clin Nutr 1981; 34: 555-561.

86. Allen LH, Backstrand JR, Stanek EJ, III, Pelto GH, Chavez A, Molina E, et al. The interactive effects of dietary quality on the growth and attained size of young Mexican children. Am J Clin Nutr 1992; 56: 353-364.

87. Murphy SP, Allen LH. Nutritional importance of animal source foods. J Nutr 2003; 133: 3932S3935S.

88. Neumann CG, Bwibo NO, Murphy SP, Sigman M, Whaley S, Allen LH, et al. Animal source foods improve dietary quality, micronutrient status, growth and cognitive function in Kenyan school children: background, study design and baseline findings. J Nutr 2003; 133: 3941S-3949S.

89. Patrick J. Interrelations between the physiology of sodium, potassium and water, and nutrition. J Hum Nutr 1978; 32: 405-418.

90. Patrick J, Golden MH. Leukocyte electrolytes and sodium transport in protein energy malnutrition. Am J Clin Nutr 1977; 30: 1478-1481.

91. Willis JS, Golden MH. Active and passive transport of sodium and potassium ions in erythrocytes of severely malnourished Jamaican children. Eur J Clin Nutr 1988; 42: 635-645.

92. Phornphatkul C, Pongprot Y, Suskind R, George V, Fuchs G. Cardiac function in malnourished children. Clin Pediatr 1994; 33: 147-154.

93. Wharton BA, Howells GR, McCance RA. Cardiac failure in kwashiorkor. Lancet 1967; ii: 384-387.

94. Wharton BA, Balmer SE, Somers K, Templeton AC. The myocardium in kwashiorkor. Q J Med 1969; 38: 107-116.

95. Smythe PM, Swanepoel A, Campbell JA. The heart in kwashiorkor. Br Med J 1962; 1: 67-73.

96. Swanepoel A, Smythe PM, Campbell JA. The heart in kwashiorkor. Am Heart J 1964; 67: 1-3. 
97. Patrick J. Death during recovery from severe malnutrition and its possible relationship to sodium pump activity in the leucocyte. Br Med J 1977; 1 : 1051-1054.

98. Grellety Y. The management of severe malnutrition in Africa Ph.D. Thesis University of Aberdeen; 2000.

99. Pickford W. Antinutrient levels in third world refugee and weaning rations: Lectin, phytate, trypsin inhibitor, chymotrypsin inhibitor and alpha amalyase inhibitor contents in rations. MSc Thesis University of Aberdeen; 1996.

100. Golden MH, Briend A, Grellety Y. Report of meeting on Supplementary feeding programmes with particular reference to refugee populations. Eur J Clin Nutr 1995; 49: 137-145. 